\title{
Arsenic cycling in the Earth's crust and hydrosphere: interaction between naturally occurring arsenic and human activities
}

\author{
Harue Masuda (D)
}

\begin{abstract}
Field-based research on naturally occurring arsenic contamination of surface waters and groundwaters and the mechanisms of contamination are reviewed. The distribution of arsenic is strongly related to areas of active plate tectonics, magmatism and associated hydrothermal activity, and high rates of erosion. Sources of arsenic contamination are mainly hydrothermal water, sulfide and arsenide minerals, volcanic ash, and iron oxyhydroxide/oxide as weathering products. The promotion of the reduction and oxidation of arsenic source minerals by in situ microbial activity is an important secondary mechanism that often determines arsenic levels in groundwater. Anthropogenic activities, such as geothermal and mining operations, as well as excess pumping of shallow groundwaters, disperse arsenic in the environment, thereby expanding areas of arsenic contamination.
\end{abstract}

Keywords: Arsenic contamination, Geologic cycle, Plate tectonics, Reduction, Oxidation

\section{Introduction}

Human beings are facing a crisis of an increasing demand for freshwater in the face of decreasing freshwater resources. One of the most serious problems threatening water resources is contamination with arsenic, which is highly toxic. Since the late 1980s, when the arsenicosis was reported in West Bengal, India (Mandal and Suzuki 2002), arsenic-contaminated groundwater and associated health disasters have occurred throughout the world, but especially in Asian countries. Arsenic is the first toxic element known to spread globally in the hydrosphere.

The World Health Organization (WHO) guidelines have recommended since 1993 that the arsenic level in aquatic solutions, including drinking water, should be $<10 \mu \mathrm{g} / \mathrm{L}$. This threshold was selected not so much because it is an epidemiologically safe level but because of the limits of analytical and treatment techniques (WHO 2006). For example, the quantification limit of arsenic by the commonly used atomic absorption spectrophotometry method is 0.001 to $0.005 \mathrm{mg} / \mathrm{L}$, much higher than the limit of $0.01 \mu \mathrm{g} / \mathrm{L}$ for inductively coupled plasma mass spectroscopy. In addition, the guideline followed differs by

Correspondence: harue@sci.osaka-cu.ac.jp

Graduate School of Science, Osaka City University, 3-3-138, Sugimoto, Sumiyoshi-ku, Osaka 558-8585, Japan 


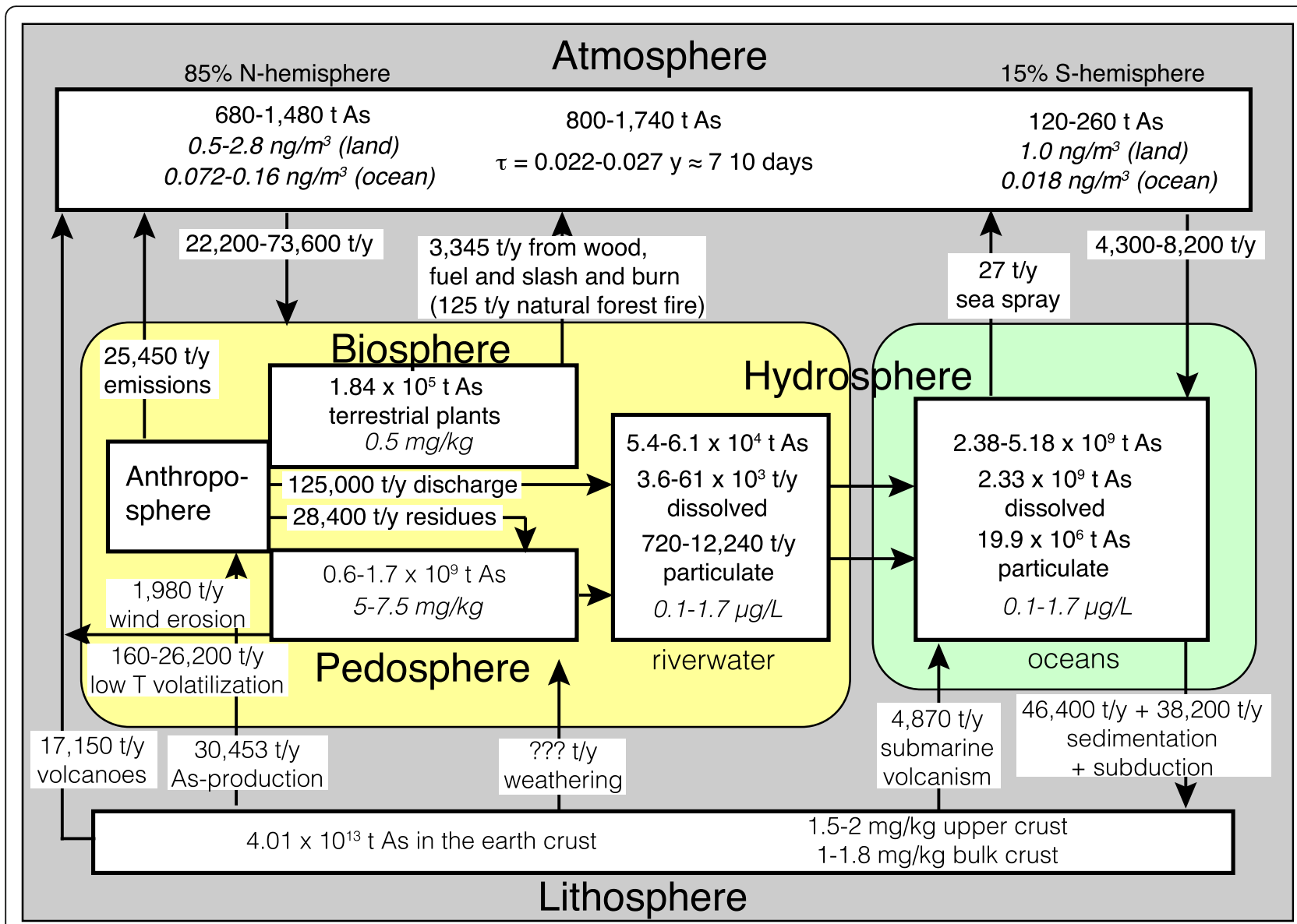

Fig. 1 Global arsenic cycle. Fluxes and reservoir sizes in different parts of the geosphere (Matschullat 2000)

of toxic arsenic compounds such as pesticides has decreased, although alloys containing arsenic continue to be used for semiconductors (JOGMEC 2012). Although anthropogenic contamination due to the application of arsenic compounds to agricultural fields is probably decreasing at least in more developed countries, activities to develop natural resources such as mining and geothermal energy extraction are a continuing cause of environmental arsenic contamination.

This review focuses on naturally occurring arsenic contamination from the points of views of geologic arsenic cycling and anthropogenic impacts on the spread of arsenic contamination.

\section{Global distribution of arsenic contamination}

There are three major natural sources of arsenic contamination: hydrothermal activity, ore deposits, and Cenozoic sediments. Other sources include coal and coal combustion. Arsenic-contaminated areas in Latin America (14 countries in Central and South America) are concentrated in the circum-Pacific region, where they are associated with the "Ring of Fire" (Fig. 2). The arsenic sources in this area are related to magmatic activity (volcanoes including volcanic ash and sulfide deposits). In addition, more than 100 aquifers along river basins in this region are contaminated with arsenic (Bundschuh et al. 2012).

High arsenic concentrations in geothermal waters reflect the fact that arsenic is a volatile component of magma and highly soluble in water. Hot-spring waters sometimes contain high concentrations of arsenic; for example, many hot springs in Yellowstone National Park, USA, are contaminated with up to $10 \mathrm{mg} / \mathrm{L}$ arsenic (Stauffer and Thompson 1984; Webster and Nordtrom 2003). Arsenic from hot springs can be transported in surface waters and enter riverbed sediments; for example, along the Owens River, arsenite released from hot springs and oxidized to arsenate in the river water by microbial activity precipitates and settles to the bottom, where it becomes a component of the riverbed sediments (0-60 mg/kg; Nimick et al. 1998). Geothermal well fluids occasionally contain higher arsenic concentrations than hot-spring waters, from $>1$ up to $50 \mathrm{mg} / \mathrm{L}$ (Webster and Nordtrom 2003 and references therein). Prior to 2000, the outflow of arsenic from Waikato Power Station, New Zealand, was $145 \mathrm{t} /$ year, but since then, it has been reduced to $\sim 70 \mathrm{t} /$ year (Webster-Brown and Lane 2005 and references therein). The large quantity 


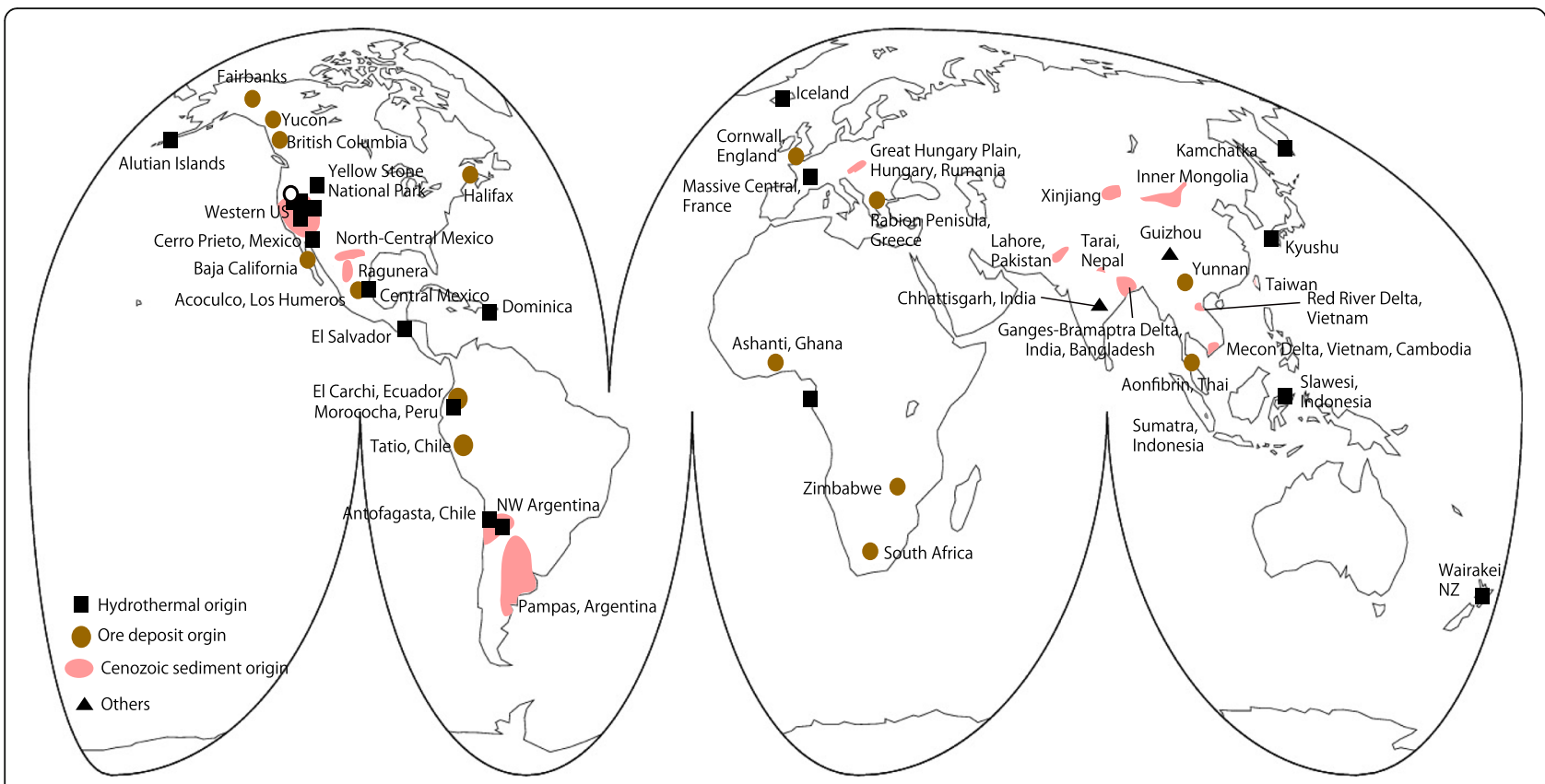

Fig. 2 World arsenic contamination map. This figure was produced based on the following reports and those in the text: Smedley and Kinniburgh (2002); Acharyya et al. (2005); An et al. (1997); Blanes et al. (2011); Camm et al. (2004); Gutiérrez-Caminero et al. (2015); Razo et al. (2004)

of arsenic in the power station drainage water has led to arsenic concentrations of $61-1790 \mathrm{mg} / \mathrm{kg}$ in the Waikato River (Webster-Brown et al. 2000).

Ore deposits are the second main source of arsenic. For example, in New Zealand, arsenic released from arsenic-bearing marcasite found in hydrothermal ore deposits formed $5 \mathrm{Ma}$ causes groundwater concentrations of $>100 \mu \mathrm{g} / \mathrm{L}$ (Craw et al. 2000). Although the distribution of naturally occurring arsenic contamination around ore bodies is generally localized, anthropogenic materials associated with the mining of ore bodies, such as tailings and sludge, expand the area of contamination into the hydrosphere and pedosphere of the surrounding area. The excavated ore bodies and the ensuing chemical weathering produce sediments highly contaminated with arsenic that then become sources of potential arsenic contamination.

The third main source of arsenic contamination is aquifers in Cenozoic sediments, which occur widely around the world (Fig. 2). The total arsenic concentration in contaminated groundwater is not extremely high compared with the average concentration in soils and sediments. For example, in a Holocene aquifer in Bangladesh, the total arsenic concentration in bulk aquifer sediments ranges from 5 to $16 \mathrm{mg} / \mathrm{kg}$ whereas $>1 \mathrm{mg} / \mathrm{L}$ arsenic has been detected in the groundwater (Seddique et al. 2011). Thus, contamination of the groundwater depends mainly on the chemical form of the arsenic host phase and the occurrence of changes to the aquatic environment that lead to the release of arsenic from the aquifer sediments rather than on the arsenic concentration in the sediments. The mechanisms by which arsenic is released from Cenozoic, especially Holocene, aquifer sediments are described in the next section.

\section{Release mechanisms of arsenic from aquifer sediments}

Naturally occurring arsenic contamination of surface waters and groundwater is associated with changes in ambient physicochemical conditions. The most important factors controlling the release of arsenic from sediments to the aquatic environment are the redox conditions and the $\mathrm{pH}$ of the water.

Arsenic contamination of groundwater is most serious, from the point of view of spatial scale and the number of affected individuals, in the Holocene aquifers along large rivers that originate in the Himalayas and on the Tibetan Plateau: for example, along the Ganges-Brahmaputra river system in Nepal, India, and Bangladesh; along the Red River in Vietnam; along the Mekong River in Cambodia and Vietnam (e.g., Charlet and Polya 2006; Fendorf et al. 2010); and along the Yellow River in Inner Mongolia, China (e.g., Smedley et al. 2003; Guo et al. 2016). Arsenic-contaminated aquifers in which ferrous and ammonium ions are dissolved in the groundwater are characterized by reducing conditions and microbial respiration (e.g., Radloff et al. 2008; Quichsall et al. 2008). Reduction of groundwater is the main mechanism causing the dissolution of arsenic in Cenozoic aquifers; the major host phase is iron oxyhydroxides/oxides, which strongly adsorb arsenic (e.g., Nickson et al. 2000; van Geen et al. 2004). 
Iron oxyhydroxides/oxides are stable under oxic (positive Eh) and weakly acid to alkaline $(\mathrm{pH}>4)$ conditions, whereas arsenic is released by desorption from or decomposition of iron oxyhydroxides/oxides under reducing and alkaline conditions (van Geen et al. 2006).

Arsenic contamination also occurs in oxic aquifers (Amini et al. 2008), where volcanic ash is often the arsenic source. For example, aquifers of the Ethiopian Rift Valley, Africa (0.6-190 $\mu \mathrm{g} / \mathrm{L}$; Rango et al. 2013), have become contaminated through the dissolution of volcanic ash under oxic conditions. Such arsenic-contaminated groundwaters formed via dissolution of volcanic ash in oxic environments are widespread in South America, especially in Argentina and Bolivia. Groundwaters in the Pampas of Argentina contain a few hundred micrograms arsenic per liter, and the mean Eh, dissolved $\mathrm{O}_{2}$, and $\mathrm{pH}$ of the contaminated groundwaters are $+73 \pm 65 \mathrm{mV}, 6.6$ $\pm 2.2 \mathrm{mg} / \mathrm{L}$, and $6.9-8.9$, respectively. The level of contamination is in general lower in oxic than in anoxic aquifers, although the arsenic concentration in the aquifers of the Pampas can be as high as $15,000 \mu \mathrm{g} / \mathrm{L}$ (Bundschuh et al. 2012 and references therein; Nicolli et al. 2012). In a semi-arid climate, intense chemical weathering of volcanic ash during the rainy season and carbonate precipitation from the water during the dry season produce alkaline conditions. Arsenic concentrations in South America are secondarily controlled by the adsorption-desorption affinity of iron oxyhydroxides produced by chemical weathering (Bundschuh et al. 2012). An alkaline arsenic-contaminated water was observed in the pit lake of an abandoned gold mine (Savage et al. 2009) and in groundwaters in Punjab, Pakistan, where the arsenic concentration can reach $1900 \mu \mathrm{g} / \mathrm{L}$, plausibly as a result of chlorite weathering at a pH range from 6.9 to 8.0 under oxic conditions without dissolved iron (Farooqi et al. 2007a, 2007b; Masuda et al. 2010).

\section{Distribution of arsenic in Japan}

A geochemical map of arsenic in the Japanese islands (Imai et al. 2004) was produced using data from elemental analyses of riverbed sediments, which generally reflect the average concentrations in the surrounding geology (Fig. 3). It is notable that arsenic is distributed along the active volcanic front in Northeast Japan and Kyushu, but it is associated with Cretaceous to Neogene igneous rock bodies on western Honshu Island.

Hydrothermal activity has been reported to cause arsenic contamination in many hot spring areas of Japan since the 1950s; for example, in Beppu (Kyushu) (Kawakami et al. 1956), Tamagawa (Akita, Northeast Japan) (Minami et al. 1958), Hakone, Yugawara (Kanagawa) (Awaya et al. 2002), and Toyohira (Hokkaido) (Jin et al. 2012). In Kusatsu-Shirane (Gunma), hot-spring water with an arsenic concentration of up to $7 \mathrm{mg} / \mathrm{L}$ flowed into the Yukawa River from the middle 1980s to the 1990s (Kikawada et al. 2006, 2009). A maximum arsenic concentration of $3.4 \mathrm{mg} / \mathrm{L}$ was reported in hydrothermal water at Kakkonda Geothermal Plant (Akita) (Okada et al. 2002).

One of the most serious Japanese arsenic disasters occurred at Toroku mine, Miyazaki (Kyushu), where arsenite was mined from the 1820s to 1962; in 1990, 146 people were found to be suffering from arsenicosis due to inhalation of refining soot and drinking contaminated water (Shimada 2009). Mining and smelting activities often cause arsenic contamination to be spread to air, sediments, and streams, whereas in the absence of such activities, it is usually confined to a small area (as noted in the "Global distribution of arsenic contamination" section). In a study in the Hokusetsu Mountains, Osaka Prefecture, on the eastern edge of the Cretaceous-Neogene magmatic bodies of western Honshu, Even et al. (2017) observed that hornfels with a high arsenic content near the granitic complex led to arsenic contamination of the surrounding ground and surface waters. Although many sulfide mines are present in this area, they are not as important as sources of arsenic contamination as the arsenide disseminated in hornfels and shales. Similarly, leaching and oxidation of arsenic in disseminated hydrothermal gold ore deposits hosted in Miocene sedimentary rock led to arsenic contamination of shallow groundwater in Sulawesi, Indonesia (Iskandar et al. 2012). The mechanism of arsenic contamination in both cases was probably oxidation and decomposition reactions of oxic water infiltrating through a fault system with diffusively distributed sulfides and arsenides.

In addition, Shimada (1996) reported that 2635 of 11,673 wells $(22.6 \%)$ in the Cenozoic aquifer beneath Tsukushi Plain, Fukuoka Prefecture (northeast Japan), contained $>10 \mu \mathrm{g} / \mathrm{L}$ of arsenic. Fortunately, however, no cases of arsenicosis have been reported from this area.

\section{Geologic cycling of arsenic}

Arc magmatism and subsequent hydrothermal activity, together with high rates of erosion and transport to sedimentary basins downstream, contribute to contamination via in situ decomposition of arsenic-containing minerals. Tectonics plays a major role in determining erosion rates, which is partly ascribable to steeper slopes produced by active crustal movement (Hecht and Oguchi 2017). Thus, plate tectonics play an important role in the geologic cycling of arsenic. In this section, the geologic cycling of arsenic is documented (Fig. 4).

Arsenic is both a siderophile and chalcophile element that can behave as a metal and combine with sulfur; however, in molten rock, it shows volatile behavior, similar to the light rare earth elements (Sims et al. 1990). As of 2014, arsenic has been shown to occur in 568 


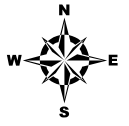

As

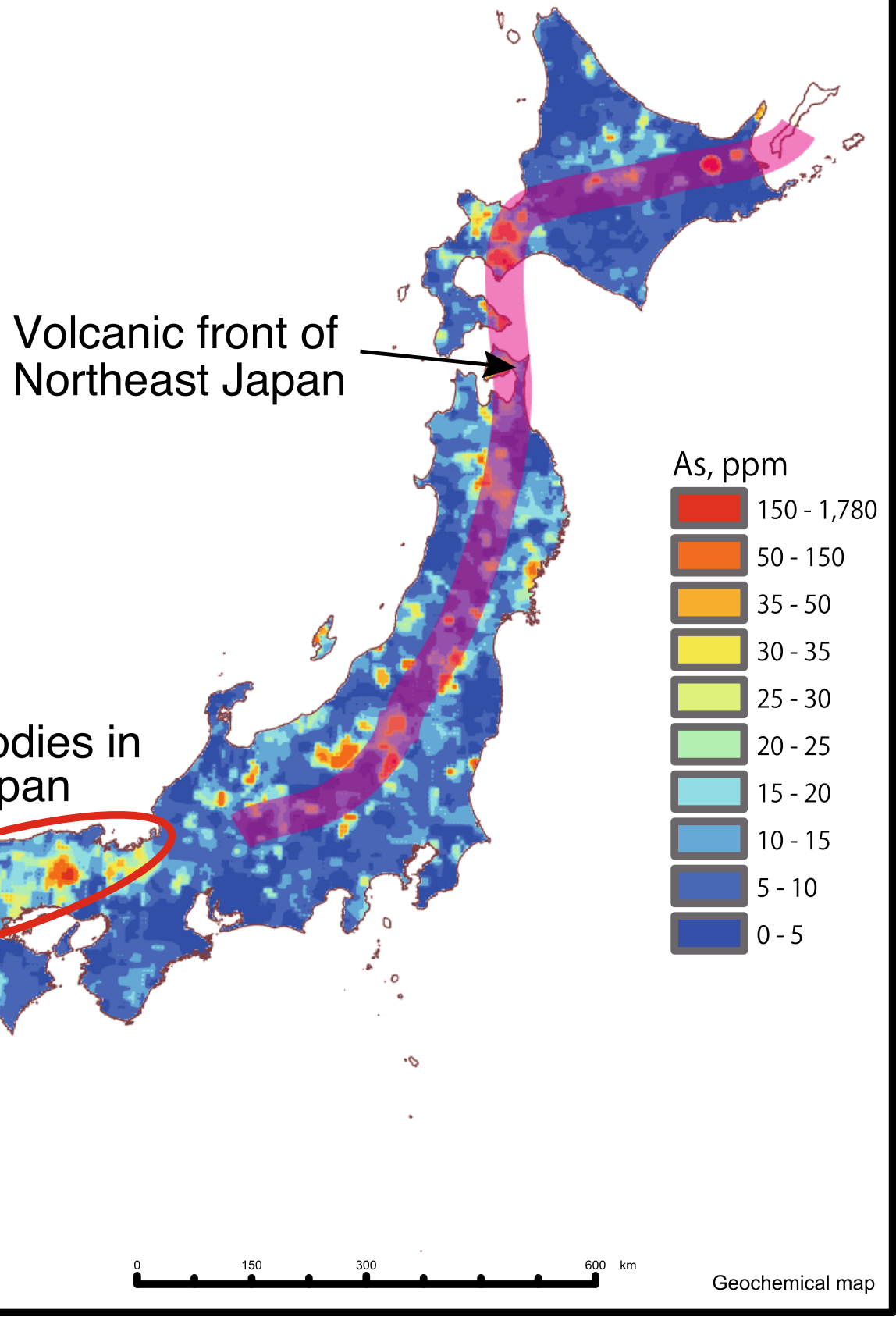

Fig. 3 Geochemical map showing arsenic distribution of riverbed sediments of Japan (Imai et al. 2004). The areas indicating volcanic fronts and plutonic rock ranges are added for this report

different mineral species (Nordstrom et al. 2014). The primary arsenic-containing mineral species are sulfides and arsenides, which form abundantly in association with magmatism and related hydrothermal activities. These include realgar $\left(\mathrm{As}_{4} \mathrm{~S}_{4}\right)$, orpiment $\left(\mathrm{As}_{2} \mathrm{~S}_{3}\right)$, arsenopyrite (FeAsS), and enargite (CuAsS). Other sulfide minerals are also primary sources of arsenic, especially pyrite, which can contain $>2 \%$ arsenic (e.g., pyrite in the
Mother Lode Gold District of California; Savage et al. 2000). Pyrite is commonly distributed not only in igneous rock bodies but also in sedimentary formations; for example, under strongly reducing conditions, arsenic is incorporated into authigenic pyrite during sediment diagenesis (e.g., Masuda et al. 2005; Saunders et al. 2008).

The partition coefficient of arsenic between sulfide and silicate melts varies as a function of oxygen fugacity; at a 


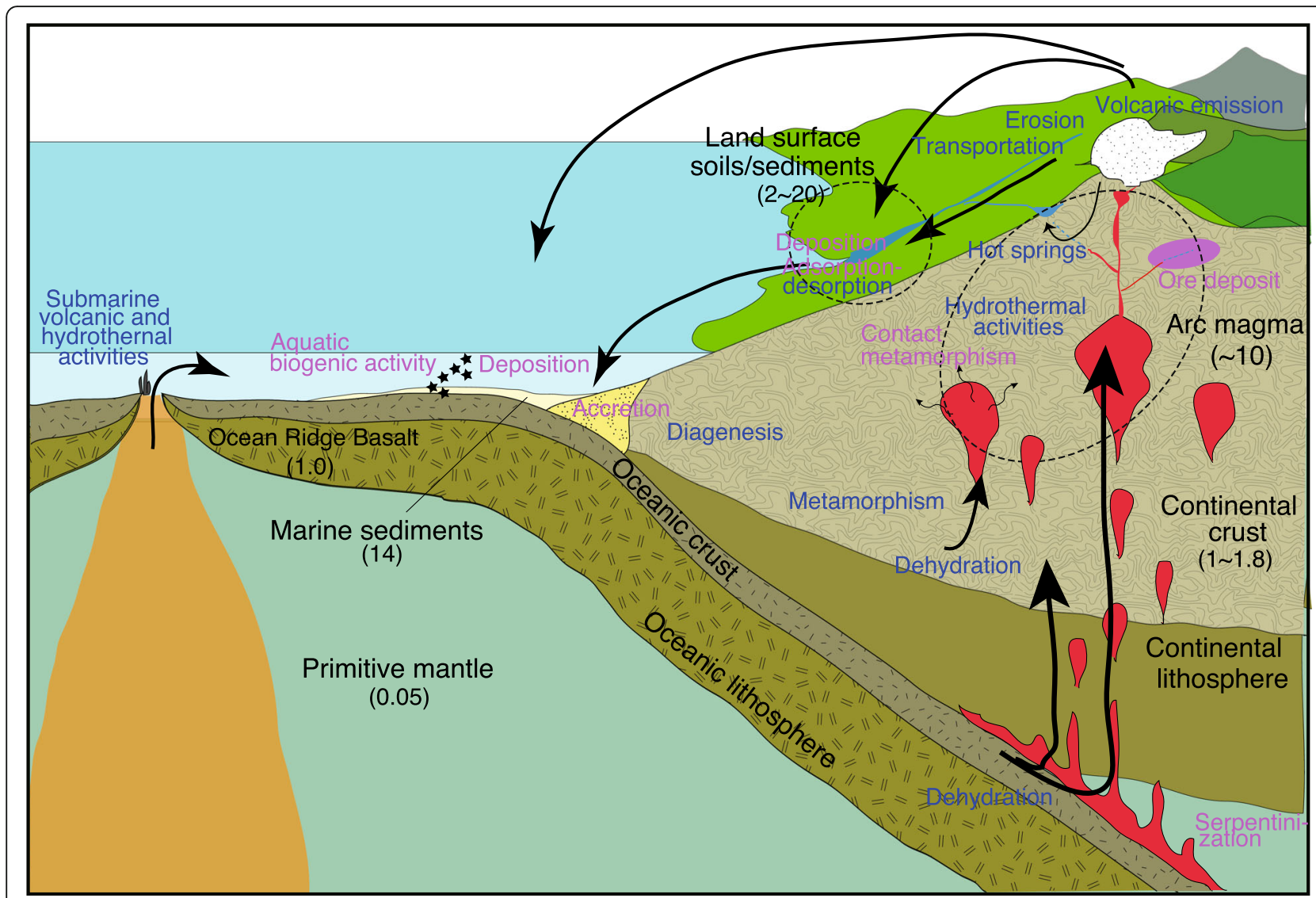

Fig. 4 Geologic cycle concerning redistribution of arsenic. Digit in parenthesis gives the average concentrations of each geologic body (references are in the text). Purple and blue colored letters indicate the releasing and fixing mechanism of arsenic in the cycle

given temperature and $\mathrm{FeO}$ content, the proportion of arsenic in silicate and monosulfide melts increases with oxygen fugacity ( $\mathrm{Li}$ and Audétat 2012, 2015). Although silicate and carbonate mineral phases do not host arsenic as a major element (Majzlan et al. 2014), under conditions of low temperature, high oxygen fugacity, and low sulfur fugacity, silicates and carbonates can incorporate arsenic; for example, filatovite $\left(\mathrm{K}[\mathrm{Al}, \mathrm{Zn}]_{2}(\mathrm{As}, \mathrm{Si})_{2} \mathrm{O}_{8}\right)$, a variety of feldspar, has been found to be associated with volcanism in Kamchatka (Vergasova et al. 2004). Charnock et al. (2007) also found that arsenic was incorporated into garnet in the overgrowth of a hydrothermal vein, and Pascua et al. (2005) found arsenic-enriched smectite in hydrothermal precipitates at a geothermal plant in Akita, Japan. In addition, Ryan et al. (2011) reported that groundwater in the fracture zone of ultramafic rocks was contaminated with arsenic derived from serpentine and magnesite via chemical weathering.

McDonough and Sun (1995) estimated the arsenic concentration of Earth's primitive mantle to be $0.05 \mathrm{mg} / \mathrm{kg}$. Hattori et al. (2002) analyzed mantle xenoliths and found that arsenic was highly concentrated in microscale sulfide minerals, and they reported that its concentration was higher in lherzolite than in harzburgite from the same area. For example, concentrations in sulfide minerals from lherzolite and harzburgite in Lesotho were $>200 \mathrm{mg} / \mathrm{kg}$ and $<14 \mathrm{mg} / \mathrm{kg}$, respectively. In addition, comparative analyses of mantle xenoliths of Ichinomegata, Japan, showed that arsenic was depleted in wedge mantle, where microscale sulfide minerals had arsenic concentrations of $<50 \mathrm{mg} / \mathrm{kg}$ (Hattori et al. 2002).

Norr et al. (1996) reported arsenic concentrations of $\sim 10 \mathrm{mg} / \mathrm{kg}$ in arc magmas enriched by hydrothermal fluids derived from metamorphic dehydration of the subducting slab, and they confirmed the release of arsenic from the subducting slab by both laboratory experiments and analyses of field-collected samples. You et al. (1996) conducted laboratory hydrothermal experiments in which they reacted sediment from the Nankai Trough, where the Philippine Sea Plate is subducting beneath the Eurasian Plate, with a synthetic $\mathrm{NaCl}-\mathrm{CaCl}_{2}$ solution and showed enrichment of the hydrothermal solution with arsenic at the relatively low temperature of $\sim 300{ }^{\circ} \mathrm{C}$. However, in relatively cool subduction zones such as that in which the Catalina Schist formed, less fore-arc devolatilization of arsenic occurs, and arsenic is 
more likely to be deeply subducted, resulting in arsenic-enriched arc lavas (Bebout et al. 1999). Arsenic-bearing serpentine, possibly formed by alteration of fore-arc mantle, has been found in the Himalayas, where the arsenic was derived from fluid from the subducting slab (Hattori et al. 2005). Norr et al. (1996) documented a decrease in the arsenic concentration of arc lavas on the order of $85 \%$, in some cases as much as $95 \%$, from fore-arc to back-arc along convergent margins. Arsenic is also released from deep continental and island-arc crust during the low-temperature and high-pressure metamorphism that forms pelitic schists; in rocks from the Sambagawa metamorphic belt, Japan, the arsenic concentration decreased from $\sim 10 \mathrm{mg} / \mathrm{kg}$ to 0 as the temperature of metamorphism increased from 300 to $450{ }^{\circ} \mathrm{C}$ (Fujiwara et al. 2011).

Submarine hydrothermal fluids from the East Pacific Rise and the Mid-Atlantic Ridge contain up to $80.5 \mu \mathrm{g} / \mathrm{L}$ and $24 \mu \mathrm{g} / \mathrm{L}$ of arsenic, respectively, whereas those from back-arc basin and island-arc locations are much higher $(1386 \mu \mathrm{g} / \mathrm{L}$ and $5850 \mu \mathrm{g} / \mathrm{L}$, respectively; Breuer and Pichler 2013). Most arsenic in hydrothermal solutions hosted by basalt in Iceland is complexed with sulfur (i.e., As $(\mathrm{OH}) \mathrm{S}_{2}{ }^{2-}, \mathrm{AsS}_{3} \mathrm{H}^{2-}$, $\mathrm{AsS}_{3}{ }^{3-}$, $\mathrm{As}(\mathrm{SH})_{4}{ }^{-}$; Sigufusson et al. 2011). Arsenic and sulfur form covalent bonds, and these chemical species precipitate from the hydrothermal solution as arsenide and sulfide minerals. Thus, many sulfide minerals, such as pyrite, contain arsenic as an impurity. As the temperature of the hydrothermal solution decreases and its oxygen fugacity increases, arsenic-sulfur complexes are decomposed and oxidized to arsenites, which are commonly found in hot-spring water where it flows out at the surface.

The arsenic concentration of Earth's crust is 1 to $1.8 \mathrm{mg} / \mathrm{kg}$ on average (e.g., Taylor and McLennan 1985; Wedepohl 1995), and all types of rocks and sediments contain arsenic at concentrations on the order of milligrams per kilogram (Table 1). Surface sediments and soils in various parts of the world contain higher and more variable concentrations, ranging from 2 to $20 \mathrm{mg} /$ $\mathrm{kg}$ on average, than the average crustal concentration (Mandal and Suzuki 2002 and references therein). The average arsenic concentration in 3024 marine sediment samples from coastal Japan was determined to be $14 \mathrm{mg} / \mathrm{kg}$, with a maximum concentration of $\sim 580 \mathrm{mg} /$ $\mathrm{kg}$; however, $65 \%$ of the sediments had $<10 \mathrm{mg} / \mathrm{kg}$, and $87.5 \%$ had $<20 \mathrm{mg} / \mathrm{kg}$ (AIST: https://gbank.gsj.jp/geo chemmap/ocean/data/ganyuryo/ocean-noudo.csv). Sediments with high concentrations of arsenic in inland areas of Japan are associated with coal and sulfide mines (Ohta et al. 2010).

Solubilities of sulfide and arsenide minerals in water are generally low, and in anoxic environments, these minerals are insoluble. For example, under standard
Table 1 Arsenic concentrations of rocks and sediments

\begin{tabular}{lll}
\hline Rock type & $\begin{array}{l}\text { Average As } \\
\text { concentration } \\
(\mathrm{mg} / \mathrm{kg})\end{array}$ & $\begin{array}{l}\text { Range of } \\
\text { concentration } \\
(\mathrm{mg} / \mathrm{kg})\end{array}$ \\
\hline $\begin{array}{l}\text { Igneous rock } \\
\text { Basalt }\end{array}$ & 2.3 & $0.18-113$ \\
Andesite & 2.7 & $0.5-5.8$ \\
Granite & 1.3 & $0.2-15$ \\
Metamorphic rock & 18 & \\
Slate & & $0.5-143$ \\
Sedimentary rock, sediments & $3-15$ & $<490$ \\
Shale/submarine shale & 14 & $0 \sim 580$ \\
Marine sediments & & \\
Sandstone & 4.1 & $0.6-120$ \\
Limestone/dolomite & 2.6 & $0.1-20.1$ \\
Evaporite & 3.5 & $0.1-10$ \\
Ferrigenous sedimentary rocks & & $1-2900$ \\
River and lake sediments & 5 & $<1-13,000$ \\
Soli & & $0.4-100$ \\
Peaty soil & 13 & $2-36$ \\
Coal & & $0.3-35,00$ \\
\hline
\end{tabular}

Edited data from Boyle and Jonasson (1973) and Smedley and Kinniburgh (2002)

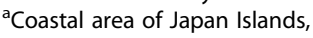

AIST https://gbank.gsj.jp/geochemmap/ocean/data/ganyuryo/ocean-noudo.csv

temperature and pressure conditions, the solubility coefficient (as $\log \mathrm{K})$ of realgar (AsS) is -83.13 , and that of orpiment $\left(\mathrm{As}_{2} \mathrm{~S}_{2}\right)$ is -180.43 (Boyle and Jonasson 1973). However, in oxic waters, those minerals are easily oxidized to dissolve. Typically, during chemical weathering of arsenic ore deposits and subsequent soil formation, arsenic host phases change as follows: arsenopyrite and löllinite in the ore body become scorodite, pharmacosiderite, and arsenosiderite in the weathered rock, and then arsenic-bearing goethite in soil (Majzlan et al. 2014). In the alteration products, arsenate ion substitutes for sulfate ion under neutral to alkaline conditions (Fernández-Martínez et al. 2008). Because in general arsenite and arsenate minerals (e.g., scorodite) are highly soluble in aqueous solution, except under strongly acidic conditions, these minerals are often sources of arsenic contamination. In fact, weathering products can be more important sources of arsenic contamination than primary source rocks and minerals as a result of secondary enrichment and their higher solubilities. For example, bulk arsenic concentrations in soils, sediments, and weathered crust from river basins in the Mother Lode District, California, are higher $(>2000 \mathrm{mg} / \mathrm{kg}$ at the maximum) than concentrations in nearby host rocks $(<600 \mathrm{mg} / \mathrm{kg})$ (Savage et al. 2000).

In arsenic-contaminated Cenozoic aquifers, arsenic is hosted mainly in iron oxyhydroxides/oxides, especially 
goethite, which is a weakly crystallized product from ferrihydrite (amorphous iron hydroxides) via chemical weathering of iron-bearing minerals. However, few studies have examined the site of iron oxyhydroxides/oxide precipitation and the incorporation of arsenic into the aquifer sediments. Dissolved arsenic in the Red River of Vietnam is probably derived from sulfide mineral smelting operations at upstream locations in China (Cui et al. 2014). However, waste arsenic from smelting operations cannot be the source of the arsenic in the Quaternary sediment aquifers of the delta. In the Red River delta, the major mechanism of arsenic contamination of groundwater is probably reduction of arsenic-bearing iron oxyhydroxide minerals (e.g., Berg et al. 2007). Instead, arsenic-bearing iron hydroxides/oxides in the delta sediments are probably chemical weathering products transported from an upstream source area. In situ decomposition of arsenic-bearing pyrite occurring in association with seasonal changes of the groundwater level was presumed to be the cause of arsenic contamination in Munshuganj, Bangladesh (Pollizzotto et al. 2005), whereas in situ chemical weathering of chlorite was inferred to be the main mechanism in Sonragaon, Bangladesh (Masuda et al. 2012, 2013). The results of these studies imply that the source of arsenic contamination in aquifers of the Ganges-Brahmaputra delta is in situ dissolution of arsenic from primary minerals rather than dissolution of or desorption from arsenic-bearing iron oxyhydroxides. Moreover, excess use of groundwater would accelerate such dissolution by promoting inductive recharge of surface water and rapid changes in chemical conditions.

\section{Biogeochemical reactions related to arsenic contamination}

Biogeochemical reactions are another factor controlling arsenic behavior, especially in the hydrosphere and pedosphere. Primary production affects arsenic behavior, especially in surface waters, because of the similarity of the chemical characteristics of $\mathrm{As}(\mathrm{V})$ and phosphorous. Clean open-ocean water contains $1.5 \mu \mathrm{g} / \mathrm{L}$ arsenic on average (Andreae 1978), whereas in terrestrial waters, the background level of arsenic is $<0.1 \mu \mathrm{g} / \mathrm{L}$ (Matschullat 2000), but the concentration varies widely, depending on the geology and on the presence of anthropogenic sources along the channels. Biological alteration of arsenic compounds in surface waters has been well documented. Andreae (1978) showed that As(III), DMAA(V) (dimethylarsinic acid), and MMAA (V) (monomethylarsonic acid) are produced in association with increasing phytoplankton activity in Donner and Squaw lakes in California, and since then, numerous studies have documented that increasing eutrophication of estuaries is globally associated with the reduction of arsenate and organo-arsenical production. For example, arsenite and methyl-arsenic species became dominant in Lake Biwa water as biological activity increased (Hasegawa et al. 2010). Seawater contains as much as $1.8 \mu \mathrm{g} / \mathrm{L}$ arsenic, and the arsenic is sometimes concentrated by marine biological activity. For example, arseno-sugar compounds concentrate in phytoplankton and algae, and arseno-betaine concentrates in marine animals (Edmonds et al. 1997). Derivatives such as monomethylarsonic acid can also form by in situ microbial methylation (Reimer and Thompson 1988). In coastal areas, organo-arsenic compounds, mostly derived from marine biological activity, account for $<1 \%$ of total arsenic in surface sediments (Takeuchi et al. 2005). Takeuchi et al. (2005) noted that organo-arsenic compounds in marine sediments are decomposed by microbial activity within several decades; therefore, the formation rate of new organo-arsenic compounds is smaller than their degradation rate.

Microbial metabolic activity also plays a key role in the cycling of arsenic in the geosphere, including in groundwater aquifers, because microorganisms transform the arsenic into more mobile forms (Oremland and Stolz 2003; Yamamura and Amachi 2014). Microbially mediated metabolic activity involving arsenic can be categorized into four processes: (1) arsenite oxidation, (2) arsenate respiration, (3) arsenate reduction, and (4) arsenite methylation (Mukhopadhyay et al. 2002; Cai et al. 2013). Arsenic-metabolizing microbes were first identified in geologic bodies in which arsenic had become concentrated; for example, arsenite-oxidizing and arsenate-reducing bacteria were found in riverbed sediments containing mine tailings in France (Quéméneur et al. 2010). Arsenic-metabolizing bacteria are now known to be widely distributed in both contaminated and uncontaminated sediments (Cai et al. 2013).

Incubation experiments conducted with sediments from arsenic-contaminated groundwater aquifers of the Ganges-Brahmaputra delta demonstrated a relation between microbial activity and arsenic behavior; for example, arsenic was fixed in authigenic framboidal pyrite (Akai et al. 2004), and anaerobic metal-reducing bacteria worked to release arsenic from the sediments via reduction of Fe (III) (Islam et al. 2004). Zhu et al. (2008) showed that arsenic-bearing pyrite in black shale decomposed seven times faster when incubated with microbes than when incubated without microbes. These experimental results demonstrated that microbial activity can promote arsenic contamination of groundwater aquifers by changing the arsenic phase from insoluble to soluble.

Arsenic-oxidizing (Ghosh et al. 2014) and arsenicreducing bacteria (Paul et al. 2015) identified by genetic analyses of microorganisms in arsenic-contaminated groundwaters from West Bengal, India, also suggest that microbial activity plays an essential role in releasing arsenic into groundwater aquifers in that area. 


\section{Conclusions}

Although natural arsenic contamination processes of surface and groundwaters are not simple but involve various interactions among the geosphere, hydrosphere, and biosphere, contamination mechanisms have been well documented in recent decades. Arsenic contamination is widespread globally, but contaminated areas tend to concentrate in and around active tectonic zones. Large-scale contamination does not simply reflect the arsenic concentration in host rocks and sediments; the dispersal of arsenic phases is important for promoting water-mineral interactions because of the large reaction interface between minerals/materials and water. In addition, secondary arsenic minerals formed by chemical weathering likely expand the area and increase the level of contamination in association with biogeochemically promoted changes of redox and $\mathrm{pH}$ conditions in the hydrosphere.

The arsenic biogeochemical cycle affects the food chain. Inorganic arsenic compounds not only contaminate the hydrosphere, they also accumulate in biological organisms. Because inorganic arsenic compounds are more toxic than most organic arsenic compounds, their presence in agricultural products is concerning. For example, in Japan, rice is a major source of inorganic arsenic (Oguri et al. 2014). Research aimed at enhancing the understanding of the metabolic cycling of arsenic by humans would facilitate prevention and mitigation of arsenic poisoning.

Not all arsenic contamination can be mitigated, because some contamination occurs as a result of natural processes. However, by acquiring more knowledge of the natural arsenic cycle, we can find ways to minimize the area and number of people affected by arsenic contamination. Many studies have documented the chemical properties and reaction paths of arsenic species and identified arsenic-metabolizing bacteria with the aim of developing chemical treatment and bioremediation methods for arsenic-contaminated groundwaters (e.g., Takeuchi et al. 2007; Yamamura and Amachi 2014). International cooperation with regard to both scientific and practical aspects is key to preventing and mitigating arsenic disasters, especially in developing countries, where they can be particularly severe.

\begin{abstract}
Acknowledgements
I thank the session conveners of the 2017 JpGU annual meeting, especially Prof. Y. Himiyama, for giving me the opportunity to present this report, and two anonymous reviewers, for the valuable comments to improve the manuscript.
\end{abstract}

\section{Funding}

This work was supported by KAKENHI (JSPS scientific fund) \#17H01863.

\section{Author's contributions}

The author read and approved the final manuscript.

\section{Competing interests}

The author declares that there are no competing interests.

\section{Publisher's Note}

Springer Nature remains neutral with regard to jurisdictional claims in published maps and institutional affiliations.

Received: 6 February 2018 Accepted: 5 October 2018

Published online: 01 November 2018

\section{References}

Acharyya SK, Shah BA, Ashyiya ID, Pandy Y (2005) Arsenic contamination in groundwater from parts of Ambagarh-Chowki block, Chhattisgarh, India: source and release mechanism. Environ Geol 49:148-158

Akai J, Izumi K, Fukuhara H, Masuda H, Nakano H, Yoshimura T, Ohfuji H, HMd A, Akai K (2004) Mineralogical and geomicrobiological investigations on groundwater arsenic enrichment in Bangladesh. Appl Geochem 19:215-230

Amini M, Abbaspour KC, Berg M, Winkel L, Hug SJ, Hoehn E, Yang H, Johnson CA (2008) Statistical modeling of global geogenic arsenic contamination in groundwater. Environ Sci Technol 42:3669-3675

An D, He YG, Hu QX (1997) Poisoning by coal smoke containing arsenic and fluoride. Fluoride 30:29-32

Andreae MO (1978) Distribution and speciation of arsenic in natural waters and some marine algae. Deep Sea Res 25:391-402

Awaya T, Oyama M, Ishizaka N, Ita K (2002) The amount of arsenic loads of river waters and hot springs in the Hakone-Yugawara area. Ann Rep Kanagawa Onsen Chigaku Kenkyujo 33:49-70 Japanese

Bebout GE, Ryan JG, Leeman WP, Bebaout AE (1999) Fractionation of trace elements by subduction-zone metamorphism - effect of convergent-margin thermal evolution. Earth Planet Sci Lett 171:63-81

Berg M, Stengel C, Trang PTK, Viet PH, Sampson ML, Leng M, Samreth S, Fredricks D (2007) Magnitude of arsenic pollution in the Mekong and Red River deltas - Cambodia and Vietnam. Sci Total Environ 372:413-425

Blanes FS, Buchhamer EE, Giménez MC (2011) Natural contamination with arsenic and other trace elements in groundwater of the Central-West region of Chaco, Argentina. J Environ Sci Health, Part A 46:1197-1206

Boyle RW, Jonasson IR (1973) The geochemistry of arsenic and its use as an indicator element in geochemical prospecting. J Geochem Explor 2:251-296

Breuer C, Pichler T (2013) Arsenic in marine hydrothermal fluids. Chem Geol 348:2-14

Bundschuh J, Litter MI, Parvez F, Roman-Ross G, Nicolli HB, Jean JS, Liu CW, Lopez D, Armienta MA, Guilherme LRG (2012) One century of arsenic exposure in Latin America: a review of history and occurrence from 14 countries. Sci Total Environ 429:2-35

Cai L, Yu K, Yang Y, Chen B-W, Li X-D, Zhang T (2013) Metanogenic exploration reveals high levels of microbial arsenic metabolism genes in activated sludge and coastal sediments. Environ Biotechnol 97:9579-9588

Camm GS, Glass HJ, Bryce DW, Butcher AR (2004) Characterisation of a miningrelated arsenic-contaminated site, Cornwall, UK. J Geochem Explor 82:1-15

Charlet L, Polya DA (2006) Arsenic in shallow, reducing groundwaters in southern Asia: an environmental health disaster. Elements 2:91-96

Charnock JM, Polya DA, Gault AG, Wogelius RA (2007) Direct EXAFS evidence for incorporation of $\mathrm{As}^{5+}$ in the tetrahedral site of natural andraditic garnet. Am Mineral 92:1856-1861

Cox MS, Bell PF, Kover JL (1996) Arsenic supply characteristics of four cottonproducing soils. Plant Soil 180:11-17

Craw D, Chappell D, Reay A (2000) Environmental mercury and arsenic sources in fossil hydrothermal systems, Northland, New Zealand. Environ Geol 38:875-887

Cui B, Zhu M, Yang J, Yanxue J (2014) Identification of the sources of metals and arsenic in river sediments by multivariate analysis and geochemical approaches. J Soils Sed 14:1456-1468

Edmonds JS, Francesconi KA, Rippingale RJ, Morita M (1997) Arsenic transformations in short marine food chains studied by HPLC-ICP MS. Appl Organomet Chem 11:281-287

EPA (US Environmental Protection Agency) (2018) Groundwater and Drinking Water, National Primary Drinking water regulations. https://www.epa.gov/ ground-water-and-drinking-water/national-primary-drinking-waterregulations\#Inorganic (2018.05.28)

Even E, Masuda H, Shibata T, Nojima A, Chiba H, Yamanaka T (2017) Geochemical distribution and fate of arsenic in water and sediments of rivers from the Hokusetsu area, Japan. J Hydrol: Region Stud 9:34-47

Farooqi A, Masuda H, Firdous N (2007a) Toxic fluoride and arsenic contaminated groundwater in Lahore and Kasur districts, Punjab, Pakistan and possible contaminant. Environ Poll 145:837-849 
Farooqi M, Masuda H, Kusakabe M, Naseem M, Firdous N (2007b) Deteriorating quality and large extent of arsenic and fluoride contaminated alluvial aquifers from East Punjab Pakistan and factors controlling contaminant's behavior. Geochem J 41:213-234

Fendorf S, Holly HA, van Geen A (2010) Spatial and temporal variations of groundwater arsenic in South and Southeast Asia. Science 328:1123-1127

Fernández-Martínez A, Cuello GJ, Johnson MR, Bardellli F, Póman-Ross G, Charlet $L$, Trrillas $X$ (2008) Arsenate incorporation in gypsum probed by neutron, $X$ ray scattering and density functional theory modeling. J Phys Chem A 112: $5159-5166$

Fujiwara S, Yamamoto K, Mimura K (2011) Dissolution processes of elements from subducting sediments into fluids: evidence from the chemical composition of the Sanbagawa pelitic schists. Geochem J 45:221-234

Ghosh D, Bhadury P, Bouth J (2014) Diversity of arsenite oxidizing bacterial communities in arsenic-rich deltaic aquifers in West Bengal, India. Front Microbiol 5, Article 602: doi: https://doi.org/10.3389/fmicb.2014.00602

Guo HM, Zhou YZ, Jia YF, Tang XH, Jiang YX, Lu H, Han SB, Zheng H, Cao YS, Zhao WG, Zhang D, Wei C, Norra S, Zhang FC (2016) Sulfur cycling-related biogeochemical processes of arsenic mobilization in the western Hetao basin, China: evidences from multiple isotope approaches. Environ Sci Technol 50:12650-12659

Gutiérrez-Caminero L, Weber B, Wurl J, Carrera-Muñoz M (2015) Tracing toxic elements sources using lead isotopes: an example from the San Antonio-El Triunfo mining district, Baja California Sur, México. Appl Geochem 59:23-32

Hasegawa H, Raman MA, Kitahara K, Itaya Y, Maki T, Ueda K (2010) Seasonal changes of arsenic speciation in lake waters in relation to eutrophication. Sci Total Environ 407:1418-1425

Hattori K, Arai S, Clarke DB (2002) Selenium, tellurium, arsenic and antimony contents of primary mantle sulfides. Can Mineral 40:637-650

Hattori K, Takahashi Y, Guillot S, Johanson B (2005) Occurrence of arsenic (V) in forearc mantle serpentinites based on X-ray absorption spectroscopy study. Geochim Cosmochim Acta 69:5585-5596

Health Canada (2017). Guidelines for Canadian drinking water quality-summary table. Water and Air Quality Bureau, Healthy Environments and Consumer Safety Branch, Health Canada, Ottawa, Ontario

Hecht H, Oguchi T (2017) Global evaluation of erosion rates in relation to tectonics. Prog Earth Planet Sci 4:40. https://doi.org/10.1186/s40645-017-0156-3

Imai N, Terashima S, Ohta M, Mikoshiba M, Okai T, Tachibana Y, Togashi S, Matsuhisa Y, Kanai Y, Ueoka A, Taniguchi M (2004) Geochemical map of Japan. Geological survey of Japan, p 209

Iskandar I, Koike K, Sendjaja P (2012) Identifying groundwater arsenic contamination mechanisms in relation to arsenic concentrations in water and host rocks. Environ Earth Sci 65:2015-2026

Islam FS, Gault AG, Boothman C, Polya DA, Charnock JM, Chatterjee D, Lloid JR (2004) Role of metal-reducing bacteria in arsenic release from Bengal delta sediments. Nature 430:68-71

Jin K, Kobayashi S, Takeuchi S, Tatsumi K, Miura K, Narita K (2012) Determination of As (III) and As $(V)$ in river water of Toyohira, Sapporo and speciation of arsenic compounds in cyanobacteria by HPLC-ICPMS. Rep Hokkaido Inst Pub Health 62:35-41

JOGMEC (2012) Material flow of ore resources 2011: 44 Arsenic. http://mric. jogmec.go.jp/public/report/2011-07/As.pdf (Jan. 10, 2018)

Kawakami H, Nozaki H, Koga A (1956) Chemical study on Beppu Hoto spring (II) - trace elements of Peppu hot spring (II) distribution of arsenic. Nihon Kagaku Zasshi 77:1785-1789 Japanese

Kikawada K, Kawai S, Oi T (2006) Long term changes in the concentration of dissolved arsenic and its present supply in the Kusatsu hot springs Gunma Japan. Chikyukagaku (Geochemistry) 40:125-136 Japanese with English abstract

Kikawada K, Kyomen K, Oi T (2009) Behavior of arsenic in Yukawa River of the Kusatsu hot spring resource area, Gunma prefecture, Japan. J Hot Spring Science 59:81-87 Japanese with English abstract

Li Y, Audétat A (2012) Partitioning of V, Mn, Co, Ni, Cu, Zn, As, Mo, Ag, Sn, Sb, W, $\mathrm{Au}, \mathrm{Pb}$, and $\mathrm{Bi}$ between sulfide phases and hydrous basanite melt at upper mantle conditions. Earth Planet Sci Lett 355-356:327-340

Li Y, Audétat A (2015) Effects of temperature, silicate melt composition, and oxygen fugacity on the partitioning of $\mathrm{V}, \mathrm{Mn}, \mathrm{Co}, \mathrm{Ni}, \mathrm{Cu}, \mathrm{Zn}, \mathrm{As}, \mathrm{Mo}, \mathrm{Ag}, \mathrm{Sn}$, $\mathrm{Sb}, \mathrm{W}, \mathrm{Au}, \mathrm{Pb}$ and Bi between sulfide phases and silicate melts. Geochim Cosmochim Acta 162:25-45

Majzlan J, Drahota P, Filippi M (2014) Parageneses and crystal chemistry of arsenic minerals. Rev Mineral Geochem 79:17-184

Mandal BK, Suzuki KT (2002) Arsenic round the world: a review. Talanta 58:201-235
Masuda H, Mitamura M, Farooqi AM, Muhanmad N, Owada M, Okazaki K, Seddique AA (2010) Geologic structure and geochemical characteristics of sediments of fluoride and arsenic contaminated groundwater aquifer in Kalalanwala and its vicinity, Punjab, Pakistan. Geochem J 44:489-505

Masuda H, Okabayashi K, Maeda S, Seddique AA, Mitamura M, Shinoda K (2013) Sequential chemical extraction of arsenic and related elements from the Holocene sediments of Sonargaon, Bangladesh, in relation to formation of arsenic-contaminated groundwater. Geochem J 47:651-661

Masuda H, Shinoda K, Okudaira T, Takahashi Y, Noguchi N (2012) Chlorite source of arsenic groundwater pollution in the Holocene aquifer of Bangladesh. Geochem J 46:381-391

Masuda H, Yamatani Y, Okai M (2005) Transformation of arsenic compounds in modern intertidal sediments of Iriomote Island, Japan. J Geochem Explor 87: 73-81

Matschullat J (2000) Arsenic in geosphere - a review. Sci Total Environ 249:297-312

McDonough WF, Sun S-s (1995) The composition of the Earth. Chem Geol 120:223-253

McLaren RG, Naidu R, Smith J, Tiller KG (1998) Fraction and distribution of arsenic in soils contaminated by cattle dip. J Environ Qual 27:348-354

Minami H, Sato G, Watanuki K (1958) Concentrations of arsenic and lead of Tamagawa hot spring waters, Akita prefecture. Nihon Kagaku Zasshi 79: 860-865 Japanese

Mukhopadhyay R, Rozen BP, Pung LT, Silver S (2002) Microbial arsenic: from geocycles to genes and enzymes. FEM Microbiol Rev 26:311-325

NHMRC, NRMMC (2011) Australian drinking water guidelines paper 6 national water quality management strategy. National Health and Medical Research Council, National Resource Management Ministerial Council, Commonwealth of Australia, Canberra

Nickson R, McArthur JM, Ravencroft P, Burgess W, Ahmed KM (2000) Mechanism of arsenic release to groundwater, Bangladesh and West Bengal. Appl Geochem 15:403-413

Nicolli HB, Bundschuh J, Blanco MD, Tujchneider OC, Panarello HO, Dapena C, Rusansky JE (2012) Arsenic and associated trace-elements in groundwater from the Chaco-Panpean plain, Argentina: results from 100 years of research. Sci Total Environ 429:36-56

Nimick DA, Moore JN, Dalby CE, Savka MW (1998) The fate of geothermal arsenic in the Madison and Missouri Rivers, Montana and Wyoming. Water Resour Res 34:3051-3067

Nordstrom DK, Majzlan J, Königsberger E (2014) Thermodynamics properties for arsenic minerals and aqueous species. Rev Mineral Geochem 79:217-255

Norr PD Jr, Newson HE, Leeman WP, Ryan JG (1996) The role of hydrothermal fluids in the production of subduction zone magmas: evidence from siderophile and chalcophile trace elements and boron. Geochim Cosmochim Acta 60:587-611

Oguri T, Yoshinaga J, Tao H, Nakazato T (2014) Inorganic arsenic in the Japanese diet: daily intake and source. Archiv Environ Contam Toxic 66:100-112

Ohta A, Imai N, Terashima S, Tachibana Y, Ikehara K, Katayama H, Noda A (2010) Factors controlling regional spatial distribution of 53 elements in coastal sea sediments in northern Japan: comparison of geochemical data derived from stream and marine sediments. Appl Geochem 25:357-376

Okada H, Tada T, Chiba A, Nakazawa H, Mitsuhashi K, Ohara T (2002) Decontamination of geothermal water - removal of arsenic. Low Temp Sci 37:331-337 Japanese with English abstract

Oremland RS, Stolz JF (2003) The ecology of arsenic. Science 300:939-944

Pascua C, Charnock J, Polya DA, Sato T, Yokoyama S, Minato M (2005) Arsenicbearing smectite from the geothermal environment. Mineral Mag 69:897-906

Paul D, Kazy SK, Gupta AK, Pal T, Sar P (2015) Diversity, metabolic properties and arsenic mobilization potential of indigenous bacteria in arsenic contaminated groundwater of West Bengal, India. PLoS One 10:e0118735. https://doi.org/ 10.1371/journal.pone.0118735

Pollizzotto ML, Harvey CF, Sutton S, Fendorf S (2005) Processes conductive to the release and transport of arsenic into aquifers of Bangladesh. Proc Nat Acad Sci US 102:18819-18823

Quéméneur M, Cébron A, Billard P, Battaglia-Brunet F, Garrido F, Leyval C, Joulian C (2010) Population structure and abundance of arsenite-oxidizing bacteria along an arsenic pollution gradient in waters of the upper Isle River Basin, France. Appl Environ Microbiol 76:4566-4570

Quichsall AN, Bostick BC, Sampson ML (2008) Linking organic matter deposition and iron mineral transformations to groundwater arsenic levels in the Mekong delta, Cambodia. Appl Geochem 23:3088-3098

Radloff KA, Manning AR, Mailloux B, Zheng Y, Rahman MM, Huq MR, Ahmed KM, van Geen A (2008) Considerations for conducting incubations to study the 
mechanisms of As release in reducing groundwater aquifers. Appl Geochem 23:3224-3235

Rango T, Vengosh A, Dwyer G, Bianchini G (2013) Mobilization of arsenic and other naturally occurring contaminants in groundwaters of the Main Ethiopian Rift. Water Res 47:5801-5818

Razo I, Carrizales L, Castro J, Díez-Barriga F, Monroy M (2004) Arsenic and heavy metal pollution of soil, water and sediments in a semi-arid climate mining area in Mexico. Water Air Soil Poll 152:129-152

Reimer KJ, Thompson JAJ (1988) Arsenic speciation in marine interstitial water. The occurrence of organoarsenicals Biogeochem 6:211-237

Ryan PC, Kim J, Wall AJ, Moen JC, Coremthal LG, Chow DR, Sullivan CM, Bright KS (2011) Ultra-mafic derived arsenic in a fractured bedrock aquifer. Appl Geochem 26:444-457

Saunders JA, Lee M-K, Shamsudduha M, Dhakal PUA, Chowdury MT, Ahmed KM (2008) Geochemistry and mineralogy of arsenic in (natural) anaerobic groundwaters. Appl Geochem 23:3205-3214

Savage KS, Ashley RP, Bird DK (2009) Geochemical evolution of a high arsenic, alkaline pit-lake in the Mother Lode Gold District, California. Econ Geol 104: 1171-1211

Savage KS, Tingle TN, O'Day PA, Waychunas GA, Bird DK (2000) Arsenic speciation in pyrite and secondary weathering phases, Mother Lode Gold District, Tuolumne County, California. Appl Geochem 15:1219-1244

Seddique AA, Masuda H, Mitamura M, Shinoda K, Yamanaka T, Nakaya S, Ahmed KM (2011) Mineralogy and geochemistry of shallow sediments of Sonargaon, Bangladesh and implications for arsenic dynamics: focusing on the role of organic matter. Appl Geochem 2:587-599

Shimada N (1996) Geochemical conditions enhancing the solubilization of arsenic into groundwater in Japan. Appl Organomet Chem 10:667-674

Shimada N (2009) The essence of problems on groundwater and soil pollutions caused by naturally occurring heavy metals and harmful elements: arsenic. Oyo Technical Report 29:31-59 Japanese with English abstract

Sigufusson B, Gislason SR, Meharg AA (2011) A field and reactive transport model study of arsenic in a basaltic rock aquifer. Appl Geochem 26:553-564

Sims KWW, Newsom HE, Gladney ES (1990) Chemical fractionation during formation of the Earth's core and continental crust: clues from As, Sb, W, and Mo. In: HE Newson and JH Jones (Editors). Origin of the earth. Oxford Univ Press, New York, N. Y., pp. 291-317

Smedley PL, Kinniburgh DG (2002) A review of source, behavior and distribution of arsenic in natural waters. Appl Geochem 17:517-568

Smedley PL, Zhang M, Zhang G, Luo Z (2003) Mobilization of arsenic and other trace elements in fluviolacustrine aquifers of the Huhhot Basin, Inner Mongolia. Appl Geochem 18:1453-1477

Stauffer RE, Thompson JM (1984) Arsenic and antimony in geothermal waters of Yellow Stone National Park, Wyoming, USA. Geochim Cosmochim Acta 48: 2547-2561

Takeuchi M, Kawahata H, Gupta LP, Kita N, Morishiba Y, Ono Y, Komai T (2007) Arsenic resistance and removal by marine and non-marine bacteria. J Biotechnol 127:434-442

Takeuchi M, Terada A, Nanba K, Kanai Y, Owaki M, Yoshida T, Kuroiwa T, Nirei H, Komai T (2005) Distribution and fate of biologically formed organoarsenicals in coastal marine sediment. Appl Organomet Chem 19:945-951

Taylor SR, McLennan SM (1985) The continental crust: its composition and evolution. Blackwell, Oxford

van Geen A, Thoral S, Rose J, Garnier JM, Zheng Y, Bottero JY (2004) Decoupling of As and Fe release to Bangladesh groundwater under reducing conditions, part II: evidence from sediment incubations. Geochim Cosmochim Acta 68: 3475-3486

van Geen A, Zheng Y, Cheng Z, Aziz Z, Horneman A, Dhar RK, Mailloux B, Stute M, Weinman B, Goodbred S, Seddique AA, Hoque MA, Ahmed KM (2006) A transect of groundwater and sediment properties in Ariahazar, Bangladesh: further evidence of decoupling between As and Fe mobilization. Chem Geol 228:85-96

Vergasova LP, Krivovichev SV, Britvin SN, Burns PC, Ananiev W (2004) Filatovite, K $\left[(\mathrm{Al}, \mathrm{Zn})_{2}(\mathrm{As}, \mathrm{Si})_{2} \mathrm{O}_{8}\right]$, a new mineral species from the Tolbachik volcano, Kamchatka peninsula, Russia. Eur J Mineral 16:533-536

Webster JG, Nordtrom K (2003) Chapter 4 geothermal arsenic the source, transport and fate of arsenic in geothermal systems. In: Welch $\mathrm{AH}$, Stollenwerk KG (eds) Arsenic in groundwater. Kluwer Academic Publishers, Boston, pp 101-125
Webster-Brown JG, Lane V (2005) The environmental fate of geothermal arsenic in a major river system, New Zealand. In: Proceedings world geothermal congress 2005, Antalya, Turkey, 24-29 April

Webster-Brown JG, Lane V, Webster KS (2000) Arsenic in the Waikato River - an update. In: Proc the 22nd geothermal workshop, New Zealand

Wedepohl KH (1995) The composition of the continental-crust. Geochim Cosmochim Acta 59:1217-1232

WHO (World Health Organization) (2006) Guideline for drinking-water quality [electronic resource]: incorporating first addendum. Vol. 1, Recommendations. $-3^{\text {rd }}$ ed. WHO Press, Geneva, Switzerland, ISBN 924154696 4. pp.515

Yamamura S, Amachi S (2014) Microbiology of inorganic arsenic: from metabolism to bioremediation. J Biosci Bioeng 118:1-9

You C-F, Castillo PR, Gieskes JM, Chan LH, Spivack AJ (1996) Trace element behavior in hydrothermal experiments: implications for fluid processes at shallow depths in subduction zones. Earth Planet Sci Lett 140:41-52

Zhu W, Young LY, Yee N, Serfes M, Rhine ED, Renfelder JR (2008) Sulfide-driven arsenic mobilization from arsenopyrite and black shale pyrite. Geochim Cosmochim Acta 72:5243-5250

\section{Submit your manuscript to a SpringerOpen ${ }^{\circ}$ journal and benefit from:}

- Convenient online submission

- Rigorous peer review

- Open access: articles freely available online

High visibility within the field

- Retaining the copyright to your article

Submit your next manuscript at $\boldsymbol{\nabla}$ springeropen.com 